\title{
DIAGNOSTIC CRITERIA OF ORAL LICHEN PLANUS: A NARRATIVE REVIEW
}

\author{
Doina Iulia Rotaru ${ }^{1}$, Diana Sofineti ${ }^{2}$, Sorana D. Bolboacă ${ }^{3}$ and Adriana E. Bulboacă ${ }^{4}$ \\ ${ }^{1}$ Department of Odontology, Iuliu Haţieganu University of Medicine and Pharmacy, Cluj-Napoca, Romania; \\ ${ }^{2}$ Dental Center Cassandraplein, Eindhoven, The Netherlands; \\ ${ }^{3}$ Department of Medical Informatics and Biostatistics, Iuliu Haţieganu University of Medicine and Pharmacy, \\ Cluj-Napoca, Romania; \\ ${ }^{4}$ Department of Pathophysiology, Iuliu Haţieganu University of Medicine and Pharmacy Cluj-Napoca, \\ Cluj-Napoca, Romania
}

\begin{abstract}
SUMMARY - Oral lichen planus (OLP) is a disease with unclear etiology or pathogenesis, categorized by the World Health Organization as oral lichenoid lesions (OLL; interface mucositis or lichenoid mucositis) into a group of potentially malignant disorders. The diagnosis of OLP is challenging because the clinical and histopathologic features are frequently seen in OLP, OLL and/or other mucosal diseases with lichenoid characteristics. Furthermore, OLP has a dynamic nature. Finally, an early and precise diagnosis can play a decisive role, allowing timely treatment and thus improving the patient quality of life. This article summarizes the state-of-the-art regarding OLP and OLL and discusses the challenges faced on making an accurate diagnosis, aiming to provide a practical guideline for the postgraduates and oral physicians in reaching the diagnosis of these lesions.
\end{abstract}

Key words: Lichen planus; Oral lichen planus; Oral lichenoid lesions; Diagnosis guideline; Precancerous conditions

\section{Introduction}

Lichen planus $($ Greek leichen $=$ tree moss, Latin planus $=$ flat, even $)^{1}$ is a common inflammatory dermatosis of unclear origin that affects the skin, nails, hair and mucous membranes, recognized as early as 1866 . The term lichen planus (LP) was coined by Wilson ${ }^{2}$, in association with the condition previously described by von $\mathrm{Hebra}^{3}$. The presence of reticulate white lines on the surface of LP papules, today known as Wickham striae $^{4}$, were first reported by Wickham in 1895. Darier presented the first description of the histopathologic features seen in $\mathrm{LP}^{5}$. A particular form of muco-

Correspondence to: Sorana D. Bolboacă, $M D, P h D$, Department of Medical Informatics and Biostatistics, Iuliu Haţieganu University of Medicine and Pharmacy, Louis Pasteur Str. no. 6, 400349 ClujNapoca, Romania

E-mail: sbolboaca@umfcluj.ro

Received October 4, 2018, accepted November 27, 2018 sal LP, which associates the presence of erosive lesions at the level of oral and vulvovaginal mucosa, was described by Pelisse et al. ${ }^{6}$.

\section{Epidemiology}

Lichen planus is distributed worldwide, but the exact incidence and prevalence are unknown due to the lack of clear diagnostic criteria, varied clinical presentation, and because the most common form of oral lichen planus (OLP, reticular) is asymptomatic and underdiagnosed $^{7}$. The prevalence of LP is estimated at $0.5 \%$ to $2.0 \%$ (e.g., $0.5 \%$ in Japan, $1.9 \%$ in Sweden, and $2.6 \%$ in India $)^{8,9}$. No racial predisposition has been reported $^{9,10}$. OLP frequently affects middle-aged or older adults, with a higher prevalence in females ${ }^{3,11,12}$, and is rare in children ${ }^{13}$.

Cutaneous LP presents as small violaceous papules most frequently localized at the flexor surfaces of the 
limbs. The 6 'Ps' of LP are 'Pruritic, Purple, Polygonal, Planar, Papules, and Plaques' ${ }^{\prime 4}$. The lesions are usually bilateral with relatively symmetric appearance.

Oral lichen planus can occur solitary or with simultaneous cutaneous or mucosal manifestations (e.g., genital area, gastrointestinal tract, eyes, etc. $)^{15}$. Oral lesions are usually bilateral, often symmetric, and most commonly involve buccal mucosa (80\%-90\% of OLP cases), gingiva and tongue ${ }^{7,16}$. Unilateral presentation of oral lesions is atypical ${ }^{7}$, and localizations on the palate, lip, and floor of the mouth are atypical ${ }^{7,16}$.

\section{Etiology}

The etiology remains uncertain, but external and internal agents are believed to be associated with OLP. The most incriminate external agents are a virus (mostly hepatitis C virus ${ }^{18,19}$ ), certain medications (such as nonsteroidal anti-inflammatory drugs; ibuprofen, diclofenac, naproxen, indomethacin, aspirin, etc.), antihypertensives (ß-blockers, thiazides, angiotensin-converting enzyme inhibitors), antirheumatics, antimalarials, gold salts, penicillamine, or retroviral therapies ${ }^{7,20,21}$, metallic materials ${ }^{22,23}$, and/or trauma. Among internal agents, stress and heat shock protein antigen expression have received most attention ${ }^{7,24,25}$. Other etiologic factors associated with OLP include genetic predisposition, diabetes, hypertension, and infections ${ }^{7,24,25}$.

Several mechanisms of its pathogenesis have been proposed, i.e. antigenic cell-mediated immune response $^{26}$, nonspecific mechanisms ${ }^{27}$, and autoimmune response ${ }^{26,28}$.

The risk of malignant transformation of OLP ranges from $0.4 \%$ to $12.5 \%{ }^{29,31}$, the highest rate of transformation being reported for erythematous and erosive lesions ${ }^{7,9,32}$. In 2005, the World Health Organization (WHO) through the Global Oral Health Program classified OLP as a premalignant condition ${ }^{33}$. The malignant potential of OLP is still debated due to the lack of consensus on accurate diagnostic criteria, thus the diagnosis being based only on clinical presentation in some cases ${ }^{30,34}$.

\section{Pathogenesis}

Oxidative stress has been reported as being involved in OLP ${ }^{35,36}$. Saliva contains several antioxidants (uric acid, glutathione, and ascorbic acid) and its defensive mechanism is called salivary antioxidant system $^{37,38}$. Some researchers have shown lower salivary and plasma levels of total antioxidant status in erosive LP patients as compared with healthy controls. The inflammatory cellular infiltrate in LP, which consists mainly of CD4+ lymphocytes, is a well-known source of reactive oxygen species ${ }^{39}$.

\section{Clinical Presentation}

Oral lichen planus is usually bilateral ${ }^{40-43}$, symmetric or asymmetric, located on buccal mucosa, tongue, lips and/or gingiva, with fine white lines forming a lace-like network (known as Wickham's striae as a highly characteristic feature of OLP). The presence of Wickham's striae is a pathognomonic feature to define a lesion as $\mathrm{LP}^{44}$.

Three OLP white forms (reticular, papular and plaque-like) and three OLP red forms (erosive (ulcerated), atrophic (erythematous) and bullous) have been reported in the literature ${ }^{45,46}$. The most common forms are reticular, erosive, papular and plaque-type, whereas the atrophic and bullous types are less frequently seen. Clinical types of OLP may occur alone or in various combinations ${ }^{27,33,47}$. No symptoms are reported for reticular lesions, whereas burning sensation and pain are reported for atrophic, erosive and bullous OLP lesions $^{48}$.

The following four types of oral lichenoid lesions (OLL) are known to date ${ }^{30,33,49}$ : lichenoid lesions in chronic graft-versus-host disease (cGVHD), oral lichenoid contact hypersensitivity reaction (OLCHR), oral lichenoid drug reactions (OLDR), and lesions with lichen planus-like aspect but missing one or several clinical characteristics (e.g., lichen planus pemphigoid, chronic ulcerative stomatitis, lupus erythematosus). Thickened white hyperkeratotic lesions with atypical localization, which typically have a straight topographic relation to the causative agent are typical for OLL ${ }^{33,50}$.

Oral squamous cell carcinoma (OSCC) could have a precursor in OLP or OLL, both bearing a risk of malignant transformation ${ }^{28,30,51,52}$, but this risk is small (1.1\% of patients with OLP develop OSCC $)^{30,53}$. Erosive OLP, especially tongue lesions ${ }^{54}$, commonly progresses into $\mathrm{OSCC}^{55,56}$. 
A higher risk of malignant transformation is reported in patients with OLL ${ }^{28,57}$; the risk increases if the patient is smoker, alcoholic, or infected with hepatitis $\mathrm{C}$ virus ${ }^{30,57}$. Although the risk of malignant transformation in patients with OLP and OLL is comparatively lower than for other potentially malignant disorders, active follow-up of all patients is mandatory $y^{30,57}$.

A reliable diagnosis of OLP and OLL has proved challenging due to both dynamic nature of the lesions and similar clinical and histologic appearances in various conditions ${ }^{30}$. Thorough medical history of the patient along with complete mucocutaneous examination before particular diagnostic tests ${ }^{58}$, and due knowledge of the clinical and pathological variations of OLP and OLL are essential to make an accurate diagnosis.

\section{Diagnostic Criteria}

Significant changes have been made over years concerning the diagnosis of OLP. According to the $\mathrm{WHO}$, there is a lack of clinical and histologic criteria for both OLP and OLL ${ }^{59}$. Diagnostic criteria for OLP were established in 1978 by the $\mathrm{WHO}^{59}$. Modified criteria were published in 2003 by van der Meij and van der Waal ${ }^{60}$, while the newest diagnostic approach for these lesions was published in 2016 (Table 1). Rad et al. ${ }^{61}$ compared the criteria set by the WHO in $1978^{59}$ with those modified by van der Meij and van der $\mathrm{Waal}^{60}$. Hiremath et al. have reported on a mild to moderate clinico-pathologic correlation in definitive diagnosis of OLP and recommended the association of the clinical and histopathologic features for definitive diagnosis ${ }^{62}$. The latest modified classification ${ }^{33}$ includes those clinical and histopathologic characteristics able to discriminate between LP and lichenoid reactions correctly.

The clinical (history and presentation), histopathologic, immunofluorescence, biomarkers, reflectance confocal microscopy, fluorescence spectroscopy, and/or therapeutic probation features detailed below support the diagnosis of OLP and OLL.

\section{Clinical history}

Oral lichen planus can be associated with stress (e.g., extension of OLP with lengthy emotional stress, increased levels of psychosocial and/or emotional stress) and/or psychological problems (especially de- pression and anxiety). Furthermore, an association with immune mediated disorders (e.g., alopecia areata, dermatomyositis, lichen sclerosus et atrophicus, morphea, myasthenia gravis, primary biliary cirrhosis, ulcerative colitis, or vitiligo $)^{9,63-65}$ could be observed.

Oral lichenoid lesions can present in three forms according to the associated conditions ${ }^{49}$, as follows: post allogeneic bone marrow transplantation (lichenoid lesions in cGVHD), dental restorations (checking the cytotoxicity of dental materials is mandatory $\left.{ }^{66}\right)$, habits of using cinnamon-containing foods or oral hygiene products (e.g., toothpaste, mouthwashes; oral lichenoid contact hypersensitivity, OLCH), or drug therapy, systemic or topical application (oral lichenoid drug reaction, OLDR), etc.

Temporal relationship between the above-mentioned elements from clinical history and the onset of oral lesions is observed.

\section{Clinical presentation}

The appearance and distribution of lesions should be considered on making the diagnosis (Table 2). OLP is frequently asymptomatic (NEOLP) or with oral symptoms such as mild burning sensation to debilitating pain which interferes with speech, chewing and swallowing (EOLP). OLP could be associated with cutaneous lesions (15\% of OLP patients develop cutaneous lesions ${ }^{49}$, which appear as purplish papules of 2-3 $\mathrm{mm}$ in diameter, with a glistening surface marked by minute fine striae, typically located on the flexor surface of the wrists and forearms, usually itchy. Skin lesions help but are not essential for making the diagnosis of $\mathrm{OLP}^{67}$ ), or with other mucosal manifestations such as genital lesions ( $20 \%$ of OLP patients have concomitant genital lesions $\left.{ }^{33}\right)$, gastrointestinal lesions $^{68-70}$, and, lesions at the level of the conjunctiva of the eyes ${ }^{71-73}$.

The following aspects are seen in all patients with OLP or OLL ${ }^{33}$ :

- the patient has multiple oral lesions or only a single isolated one;

- where the lesion(s) is/are located (list the site/ sites of involvement);

- the lesion(s) is/are limited to an area with direct contact with/adjacent to dental restoration; and

- clinical aspect of the lesion/lesions: white striations, papules, diffuse redness, ulceration surrounded by white striations or plaques, white plaques without redness, or other appearance. 
Table 1. Diagnostic criteria for oral lichen planus: changes over time

\begin{tabular}{|c|c|}
\hline Clinical criteria & Histopathologic criteria \\
\hline \multicolumn{2}{|l|}{ World Health Organization, $1978^{59}$} \\
\hline $\begin{array}{l}\text { Multiple, often symmetric in distribution: } \\
\text { - white papule, reticular (gray-white lines distributed } \\
\text { as a lace-like network), annular, or plaque-type lesions } \\
\text { - central papules with radiating gray-white lines } \\
\text { - atrophic lesions with or without erosion } \\
\text { - bullae (rare) }\end{array}$ & $\begin{array}{l}\text { - thickened orthokeratinized or parakeratinized layer } \\
\text { in usually keratinized sites; very thin layer may be } \\
\text { observed when it appears in ordinarily nonkeratinized } \\
\text { sites } \\
\text { - Civatte bodies localized at the basal, epithelium } \\
\text { and superficial layers of the connective tissue } \\
\text { - well-defined, band-like zone } \\
\text { - cellular infiltration (lymphocytes) at the level } \\
\text { of the connective tissue (superficial layer) } \\
\text { - liquefaction degeneration in the basal cell layer }\end{array}$ \\
\hline \multicolumn{2}{|l|}{ van der Meij and van der Waal, $2003^{60}$} \\
\hline $\begin{array}{l}\text { Bilateral, more or less symmetric lesions } \\
\text { reticular pattern of the lace-like network as gray-white } \\
\text { lines } \\
\text { - erosive, atrophic, bullous and plaque-type lesions just } \\
\text { in the presence of reticular lesions elsewhere in the } \\
\text { oral mucosa } \\
\text { All other lesions that resemble OLP but do not meet the } \\
\text { criteria mentioned above are called 'clinically compatible } \\
\text { with' }\end{array}$ & $\begin{array}{l}\text { - cellular infiltration (mainly lymphocytes) } \\
\text { as a well-defined band-like zone that is confined to } \\
\text { the superficial layer of the connective tissue } \\
\text { - basal cell layer with signs of liquefaction degeneration } \\
\text { - absence of epithelial dysplasia } \\
\text { When the histopathologic features are not so obvious, } \\
\text { the term 'histopathologically compatible with' is applied }\end{array}$ \\
\hline \multicolumn{2}{|l|}{ American Academy of Oral and Maxillofacial Pathology, 2016 } \\
\hline $\begin{array}{l}\text { Multifocal symmetric distribution } \\
\text { - white and red lesions exhibiting one or more } \\
\text { of the following forms: } \\
\text { - reticular/papular } \\
\text { - atrophic (erythematous) } \\
\text { - erosive (ulcerative) } \\
\text { - plaque } \\
\text { - bullous } \\
\text { - lesions are not exclusively localized } \\
\text { - to the sites of smokeless tobacco placement } \\
\text { - adjacent to and in contact with dental restorations } \\
\text { - lesion onset does not correlate with } \\
\text { - the start of a medicine } \\
\text { - use of cinnamon-containing products }\end{array}$ & $\begin{array}{l}\text { - band-like or patchy, predominately lymphocytic } \\
\text { infiltrate in the lamina propria confined to the } \\
\text { epithelium-lamina propria interface } \\
\text { - basal cell liquefactive (hydropic) degeneration } \\
\text { - lymphocytic exocytosis } \\
\text { - absence of epithelial dysplasia } \\
\text { - absence of verrucous epithelial architectural change }\end{array}$ \\
\hline
\end{tabular}

A significant weight on making clinical and definitive diagnosis of OLP lesions has the modification of clinical appearance (including unilateral or bilateral distribution), as well as changes of routines ${ }^{80}$.

\section{Histopathologic diagnosis}

The following aspects are essential regarding the histopathologic diagnosis of OLP and OLL ${ }^{33}$ :

- one tissue sample is sufficient for typical lesions; samples from multiple areas with different mu- cosal clinical features are needed in case of atypical oral lesions;

- clinical information must accompany biopsy specimen (anatomic site of lesions, clinical history, and lesion type);

- histopathologic features are variable, depending on anatomic sites, clinical type, and the stage of disease activity and/or novel treatments; and

- microscopic diagnosis of OLP and OLL lacks consensus. 
Table 2. Appearance and distribution of oral lichen planus (OLP) and oral lichenoid lesions (OLL)

\begin{tabular}{|c|c|c|}
\hline & Oral lichen planus & Oral lichenoid lesions \\
\hline Appearance & $\begin{array}{l}\text { Two or more types of OLP can co-occur } \\
\text { in a patient } t^{27,33,47,74-76} \\
\text { - reticular: most common; lacy white streaks } \\
\text { (Wickham striae) surrounded by well-defined } \\
\text { erythematous borders and lesions can cause } \\
\text { roughness and reduced mucosal flexibility } \\
\text { - papular: small white pinpoint papules that } \\
\text { may coalesce } \\
\text { - plaque-like: large, homogeneous white patches } \\
\text { - erosive: atrophic or erythematous ulcerations, } \\
\text { erosions of the mucosa, faint radiating white } \\
\text { striae } \\
\text { - atrophic: atrophic lesions surrounded by } \\
\text { erythema with radiating white striae. It } \\
\text { presents as 'desquamative gingivitis' when } \\
\text { gingiva is involved } \\
\text { - bullous: fluid-filled lesions } \\
\text { Non-erosive OLP lesions (reticular, papular } \\
\text { and plaque-like) are frequently } \\
\text { asymptomatic }{ }^{33,45,47,74,75} \text { as compared to erosive } \\
\text { OLP (EOLP, the other three lesions) }{ }^{77}\end{array}$ & $\begin{array}{l}\text { Occur in different forms similar to OLP }{ }^{49,77} \\
\text { - erythematous } \\
\text { reticular: chronic graft } v s . \text { host disease, } \\
\text { oral lichenoid drug reaction } \\
\text { - plaque-like: chronic graft } v s . \text { host disease } \\
\text { - atrophic: oral lichenoid drug reaction } \\
\text { erosive: chronic graft } v s . \text { host disease, oral } \\
\text { lichenoid drug reaction }\end{array}$ \\
\hline Distribution & $\begin{array}{l}\text { Bilateral and symmetric distribution of oral } \\
\text { lesions } 27,47,74,75 \\
\text { - reticular: posterior buccal mucosa bilaterally } \\
\text { (usually), could spread forward almost to the } \\
\text { commissures; it may also involve the lateral } \\
\text { and dorsal surface of the tongue, the gingiva, } \\
\text { and the vermilion border } \\
\text { - papular: buccal mucosa } \\
\text { - plaque-like: dorsal surface of the tongue } \\
\text { (frequently), or bilateral posterior buccal } \\
\text { mucosa } \\
\text { - atrophic/erosive: often bilateral and } \\
\text { symmetric. When EOLP involves gingival } \\
\text { mucosa it is called 'desquamative gingivitis' }\end{array}$ & $\begin{array}{l}\text { Atypical sites (such as the palate) and frequently } \\
\text { with straight topographic relation to the } \\
\text { causative agent }{ }^{79} \text { : } \\
\text { - chronic graft vs. host disease }{ }^{33} \text { : any oral } \\
\text { mucosal sites } \\
\text { - } \text { oral lichenoid contact hypersensitivity } \text { reaction }{ }^{33} \text { : in contact with dental restoration, } \\
\text { at the level of buccal mucosa and/or lateral } \\
\text { border of the tongue } \\
\text { - oral lichenoid drug reaction }{ }^{33}: \text { single oral } \\
\text { lesion (unlike bilateral, symmetric, and } \\
\text { multifocal presentations of OLP lesions) } \\
\text { - lichen planus pemphigoides }{ }^{33}: \text { buccal mucosa } \\
\text { and gingiva } \\
\text { - chronic ulcerative stomatitis }{ }^{33}: \text { gingiva } \\
\text { (may look like desquamative gingivitis), } \\
\text { tongue, and buccal mucosa } \\
\text { - lupus erythematosus }{ }^{33,37}: \text { hard palate, buccal } \\
\text { mucosa, and/or gingiva }\end{array}$ \\
\hline
\end{tabular}

A diffuse lymphocytic infiltrate mixed with plasma cells, and eosinophils are observed in the case of oral lichenoid drug reactions (OLDRs). Furthermore, inflammatory infiltrates frequently extend to the deeper connective tissue layer and a perivascular inflammatory cell infiltrate is often seen ${ }^{33,77}$. Similar microscopic features are observed in oral lichenoid contact hypersensitivity reactions (OLCHRs) and $\mathrm{OLDRs}^{33,77}$.

Nonspecific microscopic features such as hydropic degeneration of basal epithelial cells and low intensity lymphocytic infiltrate mixed with plasma cells and eosinophils in the lamina propria is seen in the case of $\mathrm{cGVHD}^{33,77}$. Lichen planus pemphigoides, as well as 
chronic ulcerative stomatitis have histopathologic characteristics similar to those of OLP ${ }^{33,77}$. In lupus erythematosus, the histopathologic features of oral lesions are similar to those found in OLP, OLDR, and $\mathrm{OLCHR}^{33,77}$. Mast cells are increased in OLP as compared to oral lichenoid reactions ${ }^{81}$.

\section{Immunofluorescence assessment}

Direct immunofluorescence (DIF) adds value to the diagnosis whenever the clinical and pathologic information is insufficient to support the diagnosis of OLP but increases the cost of diagnosis ${ }^{33}$. DIF can distinguish erosive or rare bullous OLP from pemphigus vulgaris, benign mucous membrane pemphigoid, dermatitis herpetiformis, and linear immunoglobulin A (IgA) disease. DIF sees the shaggy expression of fibrinogen in the basement membrane zone, deposition of immunoglobulin $\mathrm{M}$ as colloid bodies, and deposition of $\mathrm{C} 3$ in granular and linear patterns in OLP ${ }^{33,82}$. Furthermore, DIF finding in the perilesional tissue demonstrates a shaggy deposit of fibrin at the basement membrane zone in OLDR and IgM-positive cytoid bodies similar to those in OLP ${ }^{33}$.

The findings of DIF in OLCHR and cGVHD are similar to that of OLP and are the same in lichen planus pemphigoides and mucous membrane pemphigoid. DIF of the perilesional tissue in chronic ulcerative stomatitis reveals deposition of $\operatorname{IgG}$ autoantibodies in a speckled and/or granular pattern (also known as stratified epithelium specific-antinuclear antibody (SESANA) pattern) in the nuclei of basal and parabasal epithelial cells. DIF of tissue specimen shows granular or shaggy deposits of IgG, IgM, and/or C3 at the basement membrane zone in lupus erythematosus ${ }^{33,77}$.

Indirect immunofluorescence (IIF) is not useful in the diagnosis of OLP and shows negative results. An IIF 'string of pearls' pattern, an annular fluorescent deposit of serum antibodies, indicates OLDR. Negative IIF results are also seen for OLCHR, cGVHD, and discoid lupus erythematous. Deposits of immunoglobulins, frequently $\mathrm{IgG}$, and $\mathrm{C} 3$ at the basement membrane zone ( $\sim 80 \%$ of the cases) are identified by IIF in the case of lichen planus pemphigoides.

\section{Other diagnostic methods}

Combinations of several salivary proteins such as complement component $\mathrm{C} 3 \mathrm{c}$, fibrinogen fragment $\mathrm{D}$, and cystatin SA have been reported as salivary biomarkers for the diagnosis of OLP ${ }^{83,84}$.

In vivo reflectance confocal microscopy offers a real-time virtual biopsy of the tissues and has been used to differentiate OLP from other clinical entities.

A pilot study suggests that time-resolved fluorescence spectroscopy is a promising technology for the development of a novel OLP diagnostic technique ${ }^{85}$.

The resolution of OLLs (OLCH, OLDR) after identification and elimination of the trigger (in months or even longer) could indicate positive diagnosis (therapeutic probation). For a clear and precise definitive diagnosis, a thorough history and clinical features of lesions should be correlated with complex testing including histopathology, DIF, IIF, and cutaneous patch testing. Furthermore, diagnostic process of OLP and OLL demands continuous follow-up and, if necessary, additional biopsies for histopathologic evaluation and immunofluorescence tests.

\section{Diagnostic challenges}

Oral lichenoid lesions can be a diagnostic challenge for clinicians. A variety of diseases may have the same or very similar clinical and histopathologic features. Oral lesions associated with cGVHD, chronic ulcerative stomatitis, lichenoid drug reactions, and even lichenoid contact hypersensitivity have the same clinical characteristics as those of idiopathic OLP. Other disorders such as mucous membrane pemphigoid, lupus erythematosus, and proliferative verrucous leukoplakia can also mimic OLP. Furthermore, histopathologic features depend on anatomic sites of lesions, clinical type, and previous treatments. Accordingly, clinical information must accompany biopsy specimens.

\section{Concluding Remarks}

Oral lichen planus is a disease with unclear etiology or pathogenesis, and with unclear premalignant potential. Accurate diagnosis certainly is of paramount importance for effective management and future studies of new therapeutic options. Valid research is needed, and designs of a homogeneous group of patients with OLP could lead to more accurate diagnosis strategies, unanimously accepted and applied.

Diagnosis of OLP is established by clinical examination with histopathologic confirmation. Direct im- 
munofluorescence examination is used to rule out particular autoimmune diseases (e.g., pemphigus, pemphigoid).

Histopathologic diagnosis confirms the clinical diagnosis of OLP. The correlation between clinical and histopathologic diagnosis is crucial for definitive diagnosis of OLP. OLP necessitates additional biopsy for direct immunofluorescence assessment and/or histopathologic evaluation, so continued clinical follow-up after the initial biopsy is essential.

Oral lichenoid lesions must be distinguished from OLP by two factors. First, the association with the administration of a drug, contact with a metal or foodstuff, or presence of a systemic disease must be verified. Second, elimination of the offending agent leads to resolution of the OLL.

\section{References}

1. Daoud M, Pittelkow M. Lichen planus. In: Goldsmith L, Katz SI, Gilchrest BA, Paller AS, Leffell DJ, Wolff K (Eds.). Fitzpatrick's Dermatology in General Medicine. New York, USA: McGraw-Hill, 2012.

2. Wilson E. On lichen planus. J Cutan Med Dis Skin. 1869; 3:117-32.

3. Schifter M, Fernando SL, Li J. Oral lichen planus. In: Fernando SL (Ed.). Skin Biopsy - Diagnosis and Treatment. InTech, 2013; pp. 149-75. Available from: http://www.intechopen. com/books/skin-biopsy-diagnosis-and-treatment/oral-lichenplanus (cited June 3, 2017)

4. Wickham LF. Sur unsigne pathognomonique delichen du Wilson (lichen plan) stries et punctuations grisatres. Ann Dermatol Syph. 1895;6:17-20. (in French)

5. Black MM. The pathogenesis of lichen planus. Br J Dermatol. 1972;86:302-5. https://doi.org/10.1111/j.1365-2133.1989. tb01328.x

6. Pelisse M, Leibowitch M, Sedel D, Hewitt J. A new vulvovagino-gingival syndrome. Plurimucous erosive lichen planus. Ann Dermatol Venereol. 1982;109(9):797-8. (in French)

7. Schlosser BJ. Lichen planus and lichenoid reactions of the oral mucosa. Dermatol Ther. 2010;23:251-67. https://doi.org/ 10.1111/j.1529-8019.2010.01322.x

8. Edwards PC, Kelsch R. Oral lichen planus: clinical presentation and management. J Can Dent Assoc. 2002;68:494-9.

9. Ismail SB, Kumar SK, Zain RB. Oral lichen planus and lichenoid reactions; etiopathogenesis, diagnosis, management and malignant transformation. J Oral Sci. 2007;49:89-106. https:// doi.org/10.2334/josnusd.49.89

10. Shekar C, Ganesan S. Oral lichen planus: review. J Dent Sci Res. 2011;2(1):62-87. https://doi.org/10.4103/0975-5950.85847
11. Gorouhi F, Davari P, Fazel N. Cutaneous and mucosal lichen planus: a comprehensive review of clinical subtypes, risk factors, diagnosis, and prognosis. Sci World J. 2014;2014:742826. http://dx.doi.org/10.1155/2014/742826

12. Au J, Patel D, Campbell JH. Oral lichen planus. Oral Maxillofac Surg Clin North Am. 2013;25:93-100. https://doi. org/10.1016/j.coms.2012.11.007.

13. Scully C, de Almeida OP, Welbury R. Oral lichen planus in childhood. Br J Dermatol. 1994;130:131-3. https://doi.org/ 10.1111/j.1365-2133.1994.tb06905.x

14. Kumar V, Abbas A, Aster J. Robbins \& Cotran Pathologic Basis of Disease. $8^{\text {th }}$ edn. Philadelphia, USA: Saunders, 2009.

15. Eisen D. The evaluation of cutaneous, genital, scalp, nail, esophageal, and ocular involvement in patients with oral lichen planus. Oral Surg Oral Med Oral Pathol Oral Radiol Endod. 1999;88(4):431-6. https://doi.org/10.1016/S10792104(99)70057-0

16. Rice PJ, Hamburger J. Oral lichenoid drug eruptions: their recognition and management. Dent Update. 2002;29:442-7. https://doi.org/10.12968/denu.2002.29.9.442

17. Dudhia S, Dudhia B, Shah J. An etiological, clinical and histological study of oral lichen planus with comparative evaluation between various therapies. J Indian Acad Oral Med Radiol. 2011;23:163-8. https://doi.org/10.5005/jp-journals10011-1211

18. Calvaruso V, Craxi A. Immunological alteration in hepatitis $\mathrm{C}$ virus infection. World J Gastroenterol. 2013;19:8916-23. https: //doi.org/10.3748/wjg.v19.i47.8916

19. Carrozzo M, Brancatello F, Dametto E, Arduino P, Pentenero $\mathrm{M}$, Rendine $\mathrm{S}$, et al. Hepatitis $\mathrm{C}$ virus-associated oral lichen planus: is the geographical heterogeneity related to HLADR6? J Oral Pathol Med. 2005;34:204-8. https://doi.org/ 10.1111/j.1600-0714.2005.00303.x

20. Khudhr AS, Di Zenzo G, Carrozzo M. Oral lichenoid tissue reactions: diagnosis and classification. Expert Rev Mol Diagn. 2014;14:169-84. https://doi.org/10.1586/14737159.20 14.888953 .

21. Muller S. Oral manifestations in dermatologic disease: a focus on lichenoid lesions. Head Neck Pathol. 2011;5:36-40. https:// doi.org/10.1007/s12105-010-0237-8

22. Issa Y, Duxbury AJ, Macfarlane TV, Brunton PA. Oral lichenoid lesions related to dental restorative materials. Br Dent J. 2005;198:361-6. https://doi.org/10.1038/sj.bdj.4812176

23. Thornhill MH, Sankar V, Xu XJ, Barrett AW, High AS, Odell $\mathrm{EW}$, et al. The role of histopathological characteristics in distinguishing amalgam-associated oral lichenoid reactions and oral lichen planus. J Oral Pathol Med. 2006;35:233-40. https://doi. org/10.1111/j.1600-0714.2006.00406.x

24. Payeras MR, Cherubini K, Figueiredo MA, Salum FG. Oral lichen planus: focus on etiopathogenesis. Arch Oral Biol. 2013; 58:1057-69. https://doi.org/10.1016/j.archoralbio.2013.04.004.

25. Hegarty A. Oral lichen planus: aetiology, diagnosis and treatment. Dent Nurs. 2012;8:141-6. https://doi.org/10.12968/ denn.2012.8.3.141 
26. Muller S. The lichenoid tissue reactions of the oral mucosa: oral lichen planus and other lichenoid lesions. In: Richardson MS, ed. Current Concepts in Head and Neck Pathology. Philadelphia, USA: Saunders, 2011; pp. 1005-26.

27. Sugerman PB, Savage NW, Walsh LJ, Zhao ZZ, Zhou XJ, Khan A, et al. The pathogenesis of oral lichen planus. Crit Rev Oral Biol Med. 2002;13:350-65.

28. Roopashree MR, Gondhalekar RV, Shashikanth MC, George J, Thippeswamy SH, et al. Pathogenesis of oral lichen planus - a review. J Oral Pathol Med. 2010;39:729-34. https://doi. org/10.1111/j.1600-0714.2010.00946.x

29. Lodi G, Scully C, Carrozzo M, Griffiths M, Sugerman PB, et al. Current controversies in oral lichen planus: report of an international consensus meeting. Part I. Viral infections and etiopathogenesis. Oral Surg Oral Med Oral Pathol Oral Radiol Endod. 2005;100:40-51. https://doi.org/10.1016/j.tripleo.2004.06.077

30. Fitzpatrick SG, Hirsch SA, Gordon SC. The malignant transformation of oral lichen planus and oral lichenoid lesions: a systematic review. J Am Dent Assoc. 2014;145:45-56. https:// doi.org/10.14219/jada.2013.10.

31. Landini G, Mylonas P, Shab IZ, Hamburger J. The reported rates of transformation of oral lichen planus. J Oral Maxillofac Surg Med Pathol. 2014;26:213-20. https://doi.org/10.1016/j. ajoms.2013.04.015

32. Marttila E, Uittamo J, Rusanen P, Lindqvist C, Salaspuro M, Rautemaa R. Acetaldehyde production and microbial colonization in squamous cell carcinoma and oral lichenoid disease. Oral Surg Oral Med Oral Pathol Oral Radiol. 2013;116(1): 61-8.

33. Cheng YS, Gould A, Kurago Z, Fantasia J, Muller S. Diagnosis of oral lichen planus: a position paper of the American Academy of Oral and Maxillofacial Pathology. Oral Surg Oral Med Oral Pathol Oral Radiol. 2016;122(3):332-54. https://doi. org/10.1016/j.oooo.2016.05.004

34. Lodi G, Scully C, Carrozzo M, Griffiths M, Sugerman PB, Thongprasom K. Current controversies in oral lichen planus: report of an international consensus meeting. Part 2. Clinical management and malignant transformation. Oral Surg Oral Med Oral Pathol Oral Radiol Endod. 2005;100:164-78. https://doi.org/10.1016/j.tripleo.2004.06.076

35. Anshumalee N, Shashikanth MC, Sharma S. Oxidative stress and oral lichen planus: a possible association? Cusp. 2007;4: 31-4.

36. Ergun S, Troşala SC, Warnakulasuriya S, Özel S, Önal AE, Ofluoğlu D, et al. Evaluation of oxidative stress and antioxidant profile in patients with oral lichen planus. J Oral Pathol Med. 2011;40:286-93. https://doi.org/10.1111/j.1600-0714. 2010.00955.x

37. Battino M, Ferreiro MS, Gallardo I, Newman HN, Bullon P. The antioxidant capacity of saliva. J Clin Periodontol. 2002;29: 189-94. https://doi.org/10.1034/j.1600-051X.2002.290301x.x

38. Crnković D, Peco M, Gelo J. Correlation between salivary biochemical stress indicators and psychological indicators. Acta
Clin Croat. 2018;57:316-26. https://doi.org/10.20471/acc. 2018.57.02.13

39. Azizi A, Farshchi F. Comparison of salivary and plasma antioxidant levels in lichen planus patients and healthy subjects. J Oral Pathol Med. 2012;41:524-6. https://doi.org/10.1111/ j.1600-0714.2012.01138.x

40. Bandyopadhyay A, Behura SS, Nishat R, Dash KC, Bhuan L, Ramachandra S. Clinicopathological profile and malignant transformation in oral lichen planus: a retrospective study. J Int Soc Prevent Commun Dent. 2017;7:116-24. https://doi. org/10.4103/jispcd.JISPCD_103_17

41. Munde AD, Karle RR, Wankhede PK, Shaikh SS, Kulkurni M. Demographic and clinical profile of oral lichen planus: a retrospective study. Contemp Clin Dent. 2013;4:181-5. https://doi. org/10.4103/0976-237X.114873

42. Radochová V, Drízhal I, Slezák R. A retrospective study of 171 patients with oral lichen planus in the East Bohemia - Czech Republic - single center experience. J Clin Exp Dent. 2014; 6:e556-61. https://doi.org/10.4317/jced.51784

43. Irani S, Esfahani AM, Ghorbani A. Dysplastic change rate in cases of oral lichen planus: a retrospective study of 112 cases in an Iranian population. J Oral Maxillofac Pathol. 2016;20:3959. https://doi.org/10.4103/0973-029X.190911

44. Shirasuna K. Oral lichen planus: malignant potential and diagnosis. Oral Sci Int. 2014;11(1):1-7. https://doi.org/10.1016/ S1348-8643(13)00030-X

45. Andreasen JO. Oral lichen planus. 1. A clinical evaluation of 115 cases. Oral Surg Oral Med Oral Pathol. 1968;25:31-42.

46. Pindborg JJ, Reichart PA, Smith CJ, van der Waal I. Histological typing of cancer and precancer of the oral mucosa. $2^{\text {nd }}$ edn. New York, USA: Springer, 1997; pp. 30.

47. Mollaoglu N. Oral lichen planus: a review. Br J Oral Maxillofac Surg. 2000;38:370-7. https://doi.org/10.1054/bjom.2000.0335

48. Eisen D. The clinical features, malignant potential, and systemic associations of oral lichen planus: a study of 723 patients. J Am Acad Dermatol.2002;46:207-17. https://doi.org/10.1067 /mjd.2002.120452

49. Kamath VV, Setlur K, Yerlagudda K. Oral lichenoid lesions - a review and update. Indian J Dermatol. 2015;60(1):102. https:// doi.org/10.4103/0019-5154.147830

50. Sugerman PB, Satterwhite K, Bigby M. Autocytotoxic T-cell clones in lichen planus. Br J Dermatol. 2000;142(3):449-56. https://doi.org/10.1046/j.1365-2133.2000.03355.x

51. E1 Naggar AK, Reichart PA. Proliferative verrucous leukoplakia and precancerous conditions, In: El-Naggar AK, Chan JKC, Grandis JR, Takata T, Slootweg PJ (Eds). WHO Classification of Head and Neck Tumours. WHO Classification of Tumours, $4^{\text {th }}$ edn., 2017;9:180-1.

52. Ruokonen HMA, Juurikivi A, Kauppila T, Heikkinen AM, Seppänen-Kaijansinkko R. High percentage of oral lichen planus and lichenoid lesion in oral squamous cell carcinomas. Acta Odontol Scand. 2017;75(6):442-5. https://doi.org/10.1080/00 016357.2017.1332777 
53. Aghbari SMH, Abushouk AI, Attia A, Elmaraezy A, Menshawy A, Ahmed MS, et al. Malignant transformation of oral lichen planus and oral lichenoid lesions: a meta-analysis of 20095 patient data. Oral Oncol. 2017;68:92-102. https://doi. org/10.1016/j.oraloncology.2017.03.012

54. Bombeccari GP, Guzzi G, Tettamanti M, Giannì AB, Baj A, Pallotti F, et al. Oral lichen planus and malignant transformation: a longitudinal cohort study. Oral Surg Oral Med Oral Pathol Oral Radiol Endod. 2011;112(3):328-34. https://doi. org/10.1016/j.tripleo.2011.04.009

55. Mignogna MD, Lo Muzio L, Lo Russo L, Fedele S, Ruoppo E, Bucci E. Clinical guidelines in early detection of oral squamous cell carcinoma arising in oral lichen planus: a 5-year experience. Oral Oncol. 2001;37(3):262-7. https://doi.org/10.1016/ S1368-8375(00)00096-8

56. Kaplan BR. Oral lichen planus and squamous carcinoma: case report and update of the literature. R I Dent J. 1991;24(4):5-9, 11-4.

57. Gopalakrishnan A, Balan A, Kumar NR, Haris PS, Bindu P. Malignant potential of oral lichen planus: an analysis of literature over the past 20 years. Int J Appl Dent Sci. 2016;2:1-5.

58. Van der Meij EH, Reibel J, Slootweg P van der Wal JE, de Jong WF, van der Waal I. Interobserver and intraobserver variability in the histologic assessment of oral lichen planus. J Oral Pathol Med. 1999;28:274-7. https://doi.org/10.1111/j.16000714.1999.tb02038.x

59. WHO Collaborating Centre for Oral Precancerous Lesions. Definition of leukoplakia and related lesions: an aid to studies on oral precancer. Oral Surg Oral Med Oral Pathol Oral Radiol Endod. 1978;46:518-39.

60. van der Meij EH, van der Waal I. Lack of clinicopathologic correlation in the diagnosis of oral lichen planus based on the presently available diagnostic criteria and suggestions for modifications. J Oral Pathol Med. 2003;32:507-12. https://doi. org/10.1034/j.1600-0714.2003.00125.x

61. Rad M, Hashemipoor MA, Mojtahedi A. Correlation between clinical and histopathologic diagnoses of oral lichen planus based on modified WHO diagnostic criteria. Oral Surg Oral Med Oral Pathol Oral Radiol Endod. 2009;107:796-800. https://doi.org/10.1016/j.tripleo.2009.02.020

62. Hiremath SKS, Kale AD, Hallikerimath S. Diagnostic criteria for oral lichen planus. Turk J Pathol. 2015;31(1):24-9. https:// doi.org/10.5146/tjpath.2014.01285

63. Akay A, Pekcanlar A, Bozdag KE, Altintas L, Karaman A. Assessment of depression in subjects with psoriasis vulgaris and lichen planus. J Eur Acad Dermatol Venereol. 2002;16:347-52. https://doi.org/10.1046/j.1468-3083.2002.00467.x

64. Kalkur C, Sattur AP, Guttal KS. Role of depression, anxiety and stress in patients with oral lichen pPlanus: a pilot study. Indian J Dermatol. 2015;60(5):445-9. https://doi.org/10.4103 /0019-5154.159625

65. Agha-Hosseini F, Moosavi MS, Sadrzadeh Afshar MS, Sheykhbahaei N.Assessment of the relationship between stress and oral lichen planus: a review of literature. J Islam Dent Assoc Iran. 2016;28(2):78-85.

66. Brzović Rajić V, Želježić D, Malčić Ivanišević A, Verzak Ž, Baraba A, Miletić I. Cytotoxicity and genotoxicity of resin based dental materials in human lymphocytes in vitro. Acta Clin Croat. 2018;57(2):278-85. https://doi.org/10.20471/ acc.2018.57.02.07

67. Odell E. Cawson's Essentials of Oral Pathology and Oral Medicine. $8^{\text {th }}$ edn. Churchill Livingstone, 2008.

68. Cheng S, Kirtschig G, Cooper S, Thornhill M, Leonardi-Bee J, Murphy R. Interventions for erosive lichen planus affecting mucosal sites. Cochrane Database Syst Rev. 2012;2:CD008092. https://doi.org/10.1002/14651858.CD008092.pub2

69. Yamada T, Alpers DH, Kalloo AN, Kaplowitz N, Owyang C, Powell DW. Textbook of Gastroenterology, $5^{\text {th }}$ edn. Chichester, West Sussex: Blackwell Pub., 2009; pp. 3304.

70. Treister NS, Bruch JM. Clinical Oral Medicine and Pathology. New York: Humana Press, 2010; pp. 59-62.

71. Mucosal Lichen Planus Simultaneously Involving Oral Mucosa, Conjunctiva and Larynx. [cited 2018 Jun 26]. Available from: https://www.researchgate.net/publication/45274121_ Mucosal_Lichen_Planus_Simultaneously_Involving_Oral_ Mucosa_Conjunctiva_and_Larynx

72. Rhee MK, Mootha VV. Bilateral keratoconjunctivitis associated with lichen planus. Cornea, 2004;23:100-5.

73. Thorne JE, Jabs DA, Nikolskaia OV, Mimouni D, Anhalt GJ, Nousari HC. Lichen planus and cicatrizing conjunctivitis: characterization of five cases. Am J Ophthalmol. 2003;136: 239-43.

74. Zhao ZZ, Savage NW, Sugerman PB, Walsh LJ. Mast cell/T cell interactions in oral lichen planus. J Oral Pathol Med. 2002; 31:189-95. https://doi.org/10.1034/j.1600-0714.2002.310401.x

75. Hirota J, Osaki T, Tatemoto Y. Immunohistochemical staining of infiltrates in oral lichen planus. Path Res Pract. 1990;186: 625-32.

76. Yamamoto T, Yoneda K, Ueta E, Osaki T. Cellular immunosuppression in oral lichen planus. J Oral Pathol Med. 1990;19: 464-70. https://doi.org/10.1111/j.1600-0714.1990.tb00788.x

77. Chiang CP, Yu-Fong Chang J, Wang YP, Wu YH, Lu SY, Sun A. Oral lichen planus - differential diagnoses, serum autoantibodies, hematinic deficiencies, and management. J Formos Med Assoc. 2018;pii:S0929-6646(18)30052-4. https://doi. org/10.1016/j.jfma.2018.01.021

78. Potts AJ, Hamburger J, Scully C. The medication of patients with oral lichen planus and the association of nonsteroidal anti-inflammatory drugs with erosive lesions. Oral Surg Oral Med Oral Pathol. 1987;64:541-3.

79. Lamey PJ, McCartan BE, MacDonald DG, MacKie RM. Basal cell cytoplasmic autoantibodies in oral lichenoid reactions. Oral Surg Oral Med Oral Pathol Oral Radiol Endod. 1995; 79:44-9. https://doi.org/10.1016/S1079-2104(05)80072-1

80. Sanketh DS, Srinivasan SR, Patil S, Ranganathan K. Issues related to diagnosing oral lichen planus among oral pathologists 
in South India: a pilot survey. J Investig Clin Dent. 2017; 8(4):e12246. https://doi.org/10.1111/jicd.12246

81. Ramalingam S, Malathi N, Thamizhchelvan H, Sangeetha N, Rajan ST. Role of mast cells in oral lichen planus and oral lichenoid reactions. Autoimmune Dis. 2018;2018:Article ID 7936564. https://doi.org/10.1155/2018/7936564

82. Buajeeb W, Okuma N, Thanakun S, Laothumthut T. Direct immunofluorescence in oral lichen planus. J Clin Diagn Res. 2015;9(8):ZC34-ZZC7. https://doi.org/10.7860/JCDR/ 2015/13510.6312

83. Talungchit S, Buajeeb W, Lerdtripop C, Surarit R, Chairatvit $\mathrm{K}$, Roytrakul S, et al. Putative salivary protein biomarkers for the diagnosis of oral lichen planus: a case-control study. BMC Oral Health. 2018;18:42. https://doi.org/10.1186/s12903018-0504-8

84. Liang Fang, Qing Liu, Pengfei He, Xinwen Wang, Ying Wang, Minghui Wei, et al. Structural changes in the glycans of saliva proteins might be reliable indicators of OLP. J Biomark. 2018; 23(2):188-95.

85. Gorpas D, Davari P, Bec J, Fung MA, Marcu L, Farwell DG, et al. Time-resolved fluorescence spectroscopy for the diagnosis of oral lichen planus. Clin Exp Pathol. 2018;43(5):546-52. https://doi.org/10.1111/ced.13404

Sažetak

\section{DIJAGNOSTIČKI KRITERIJI ZA ORALNI LIHEN PLANUS: NARATIVNI PREGLED}

\section{D.I. Rotaru, D. Sofineti, S.D. Bolboacă i A.E. Bulboacă}

Oralni lihen planus (OLP) je bolest nejasne etiologije ili patogeneze. Prema Svjetskoj zdravstvenoj organizaciji kategorizira se kao oralne lihenoidne lezije (OLL; prijelazni mukozitis ili lihenoidni mukozitis) u skupinu potencijalno zloćudnih bolesti. Dijagnosticiranje OLP-a je zahtjevno, jer se klinička i histopatološka obilježja često vide u OLP-u, OLL-u i/ili drugim bolestima sluznice s lihenoidnim značajkama. Nadalje, OLP ima dinamičnu narav. Konačno, rana i precizna dijagnoza može imati odlučnu ulogu i omogućiti pravodobno liječenje te time poboljšati bolesnikovu kvalitetu života. Ovaj pregled sažima današnja saznanja o OLP-u i OLL-u te raspravlja o izazovima kod postavljanja dijagnoze, a cilj je pružiti praktične smjernice za dijagnostiku ovih promjena za postdiplomante i liječnike oralne medicine.

Ključne riječi: Lihen planus; Oralni lihen planus; Oralne lihenoidne lezije; Dijagnostičke smjernice; Predkancerozna stanja 